DOI: $\square$ https://doi.org/10.15407/techned2020.06.036

\title{
COMBINED CONTROL OF GEARLESS ARC-CORE ELECTRIC DRIVE OF A SHIP RADAR ANTENNA
}

Journal

Publisher

ISSN

Issue

Pages
Tekhnichna elektrodynamika

Institute of Electrodynamics National Academy of Science of Ukraine 1607-7970 (print), 2218-1903 (online)

No 6, 2020 (November/December)

$36-42$

\section{Authors}

V.P. Stiazhkin ${ }^{1 *}$, O.A. Zaichenko ${ }^{1 * \star}$, S.I. Gavryluk ${ }^{1 * \star *}$, V.I. Teriaiev ${ }^{2 \star \star \star *}$

1- Institute of Electrodynamics of National Academy of Sciences of Ukraine, pr. Peremohy, 56, Kyiv, 03057, Ukraine,

e-mail: tems@ukr.net, oleg_tems@ukr.net, serggtm@gmail.com

2- National Technical University of Ukraine "Igor Sikorsky Kyiv Polytechnic Institute",

Peremohy ave., 37, Kyiv, 03056, Ukraine,

e-mail: kpivit@gmail.com

* ORCID ID : https://orcid.org/0000-0003-0602-1112

** ORCID ID : https://orcid.org/0000-0001-9311-3378

*** ORCID ID : https://orcid.org/0000-0002-7345-8405

**** ORCID ID : https://orcid.org/0000-0002-8634-0895

\section{Abstract}

The calculation and analysis of the aerodynamic loads of the ship's antenna radar station are carried out. An expression is obtained of the dependence of the torque on the shaft of the antenna drive on its rotation speed, rotation angle, speed and direction of wind flow, on the basis of which a device is implemented for indirect measurement of the load torque. Has been synthesized a combined automatic control system for a gearless arc-core electric drive of the radar station antenna, the main channel of which operates according to the deviation control principle with a closed speed control loop, and the second channel, which operates according to the disturbance control principle (load torque) and has an open loop. Studies had confirmed the effectiveness of combined control, the use of corrective loop allows compensate the load effect on a given value of the speed of the antenna. References 12, figures 4. 
Key words: ship radar antenna, gearless arc-core electric drive, combined automatic control system, disturbance compensation, synthesis, research.

Received: 24.02.2020

Accepted: 20.08.2020

Published: 21.10.2020

\section{References}

1. Kalinkin D.Yu., Stolyarova O.O. Permanent magnet converter-fed motor for ship radar. IEEE, 15th International Conference of Young Specialists on Micro/Nanotechnologies and Electron Devices. Novosibirsk, Russia. June 30 - July 4, 2014. Pp. 436-439. DOI: https://doi.org/10.11 09/EDM.2014.6882566

2. Rashed. M, MacConnell P., Stronch A., Acarnley P. Sensorless indirect-rotor-field-orientation speed control of a permanent-magnet synchronous motor with stator-resistance estimation. IEE E Transactions on Industrial Electronics . 2007. Vol. 54. No 3. Pp. 1664-1675. DOI:

https://doi.org/10.1109/TIE.2007.895136

3. Ehsan Al-Nabi. Sensorless current source-fed PM drive system for low speed operations. Ryerson University, Canada. 2013. 172 p.

4. lohimovich A.D., Korovin A.V., Pankratov V.V. The development of the direct electric drive system of a radar station antenna. IEEE, 14th International Conference of Young Specialists on Micro/Nanotechnologies and Electron Devices

Novosibirsk, Russia. July 1-5, 2013. DOI:

https://doi.org/10.1109/EDM.2013.6642000

5. Jinpin Kong, Zhengfeng Xu, Boatao Wu. Research on predicting current of shipborne satcom antenna. MATEC Web of Conferences. Xiamen, China. May 29-30, 2015. Vol. 22. Pp. 1-6(02028). DOI:

https://doi.org/10.1051/matecconf/20

152202028

6. Dushinova E.V., Potapenko E.M., Deev S.G., Shibalkin O.E., Shijka A.A. Radar antenna rotation electric drive. Elektrotekhnika i elektroenergetika. 2011. No 1. Pp. 25-35. (Rus) DOI: ht tps://doi.org/10.15588/1607-6761-2011-1-4

7. Stiazhkin V.P., Teriaev V.I., Gavryluk S.I. Application of frequency control methods for arc core ship's navigation radar antennas. Visnyk Natsionalnoho Tekhnichnoho Universytetu "Kharkivsky Polytekhnichny Instytut". Problemy avtomatyzovanoho elektropryvoda. Teoriia i praktyka. Sylova elektronika ta enerhoefektyvnist 2017. No 27(1249). Pp. 411-414. (Ukr) URL: 
http://repository.kpi.kharkov.ua/handle/KhPI-Press/34122

(accessed at 15.01.2020)

8. Volianska Ya.B., Golikov V.V., Mazur O.M., Onischenko O.A., Shevchenko V.A. The system of stabilization of the ship's course, that are partially invariant to the wind-wave loads. Avtomatiz atsia tekhnologichnyh $\mathrm{i}$ biznes protsesiv

. 2019. Vol. 10. No 2. Pp. 57-63. (Ukr) DOI:

https://doi.org/10.15673/atbp.v10i2.980

9. Tomera M. Nonlinear controller design of a ship autopilot. Int. J. Appl. Math. Comput. Sci. 2010. Vol. 20. No 2. Pp. 271-280. DOI:

https://doi.org/10.2478/v10006-010-0020-8

10. Stiazhkin V.P., Gavryluk S.I. Automated control system of the gearless electro drives for navigational ship radar. Elektronika ta zviazok. 2016. No 4. Pp. 20-23. (Ukr) DOI: https://doi.or $\mathrm{g} / 10.20535 / 2312-1807.2016 .21 .4 .81914$

11. Stiazhkin V.P., Zaichenko O.A., Gavryluk S.I. Gearless electric drive of rotor of electromagnetic separator. Elektrotekhnichi ta komputerni systemy. 2019. № 31(107). Pp. 11-18. (Ukr) DOI: .org/10.15276/eltecs.31.107.2019.1

https://doi

12. Volkov I.V., Stiazhkin V.P., Milko R.E., Domanski G.V. Gearless electromechanical system with air core electro drive for radar antenna. Elektrotekhnichi ta komputerni systemy. 2011. No 3(79). Pp. 248-252. (Rus)

$\underline{\text { PDF }}$

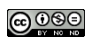

This work is licensed under a Creative Commons Attribution-NonCommercial-NoDerivatives 4.0 International License 